\title{
Entrelacs
}

Cinéma et audiovisuel

Hors-série $n^{\circ} 4$ | 2016

Paysages en séries

\section{Le Bout du monde}

\section{Marie Maillos et Maylis Asté}

\section{OpenEdition}

Journals

Édition électronique

URL : http://journals.openedition.org/entrelacs/4403

DOI : 10.4000 /entrelacs.4403

ISBN : $2261-5482$

ISSN : 2261-5482

Éditeur

Éditions Téraèdre

Édition imprimée

Date de publication : 1 novembre 2016

ISSN : 1266-7188

\section{Référence électronique}

Marie Maillos et Maylis Asté, «Le Bout du monde », Entrelacs [En ligne], Hors-série n 4 | 2016, mis en ligne le 06 février 2019, consulté le 24 septembre 2020. URL : http://journals.openedition.org/ entrelacs/4403 ; DOI : https://doi.org/10.4000/entrelacs.4403

Ce document a été généré automatiquement le 24 septembre 2020.

Tous droits réservés 


\title{
Le Bout du monde
}

\author{
Marie Maillos et Maylis Asté
}

1 Cette nature vivante, habitée par un monde végétal et animal qui en compose les paysages, a pourtant ses limites : par-delà celles-ci se dessine un autre paysage, naturel encore mais bien différent. Ce paysage est vierge, hostile à l'homme non par qualité mais par essence: aucun homme ne pourrait espérer y survivre. Tout à fait indomptable, la nature n'y est pas pour autant foisonnante : elle est espace, elle est étendue.

2 Elle est l'étendue d'eau dans laquelle plongent les amants de The Affair, qui effleurent sa surface mais se tiennent au bord; qui la regardent mais la craignent, la touchent mais ne peuvent y demeurer. Ils y croisent des fantômes et y rêvent leur vie future, à la frontière entre passé et avenir.

3 Elle est l'étendue de sable que craignaient les cow-boys, et que craignent encore aujourd'hui les personnages des séries qui s'y frottent. La confrontation à ces déserts devenus mythiques de l'Ouest américain a fait naître les grands héros contemporains et périr bien d'autres. Nombreux sont ceux qui finiront la tête dans le sable, encore aujourd'hui dans Breaking Bad.

4 Elle est le vide qui entoure le monde, et qui entoure ce qui entoure le monde. Un rien que l'on peut à la rigueur traverser, mais jamais connaître, jamais totalement appréhender. L'espace est un monde qui n'a pas été conçu à la mesure de l'homme, et dans lequel il s'humilie, au sens premier : il doit toujours retourner à la terre.

5 Qu'ils arpentent le désert, longent le rivage ou plongent dans l'espace, les héros de ces séries traversent ces paysages comme un memento mori gigantesque qui les avalerait. On entrevoit en observant ces contrées pourquoi des centaines de générations ont cru contempler - lorsque leurs yeux étaient rivés sur l'une ou l'autre de ces régions - le bout du monde. 